\title{
Modeled Inundation Limits of Potential Lahars from Mount Adams in the White Salmon River Valley, Washington
}

By Julia P. Griswold, Thomas C. Pierson, and Joseph A. Bard

Open-File Report 2018-1013

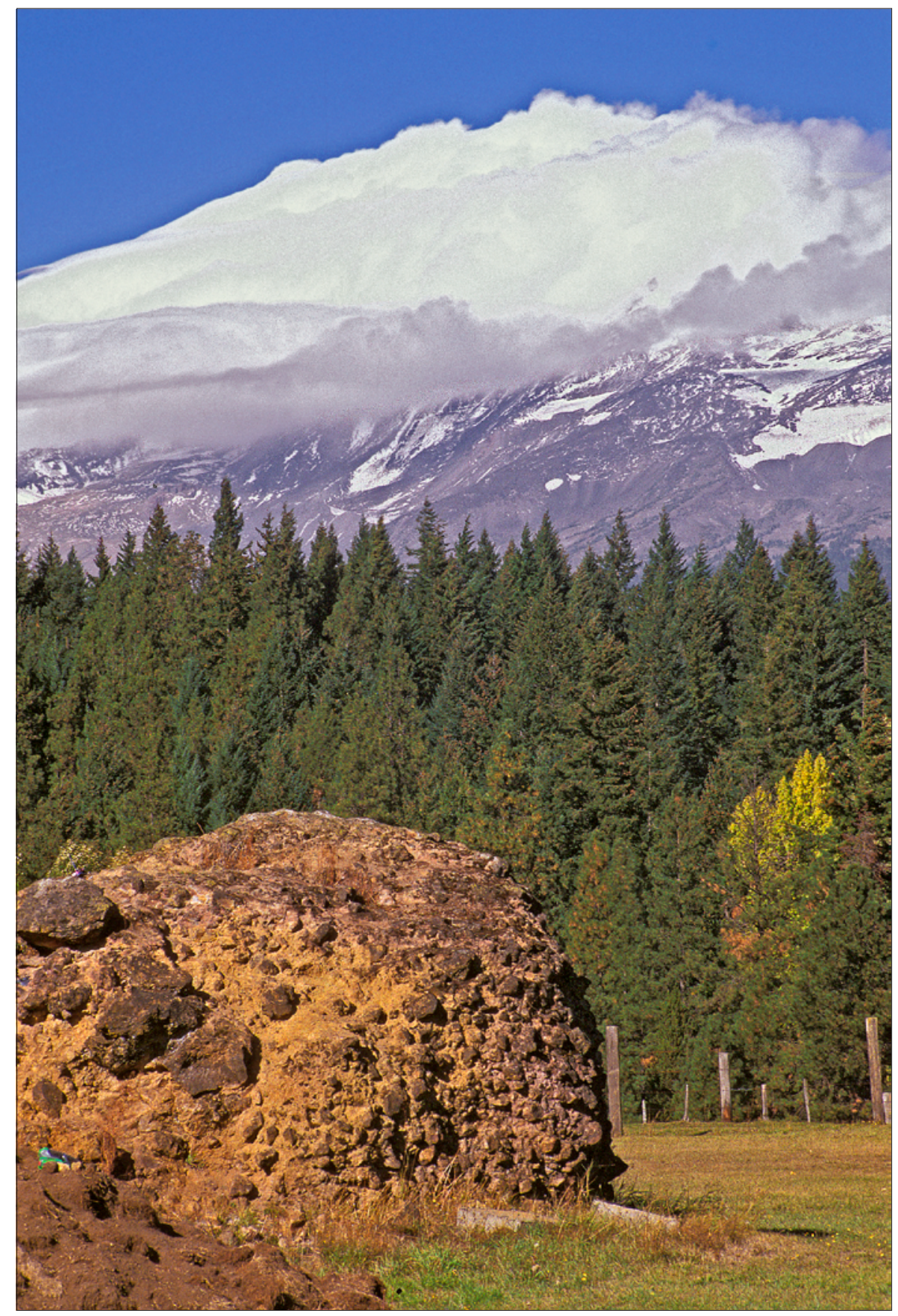

Photograph of a 10 -ft-diameter (3-m-diameter) boulder, transported from Mount Adams by a lahar to this pasture in the White Salmon River valley near Trout Lake, Washington, approximately 17 miles $(27 \mathrm{~km})$ downstream of its source on the flank of the volcano (in background). Photograph by Darryl Lloyd, used with permission. 


\section{U.S. Department of the Interior \\ RYAN K. ZINKE, Secretary}

\section{U.S. Geological Survey \\ William H. Werkheiser, Deputy Director \\ exercising the authority of the Director}

U.S. Geological Survey, Reston, Virginia: 2018

For more information on the USGS-the Federal source for science about the Earth, its natural and living resources, natural hazards, and the environment-visit https://www.usgs.gov/ or call 1-888-ASK-USGS (1-888-275-8747).

For an overview of USGS information products, including maps, imagery, and publications, visit https://store.usgs.gov/.

Any use of trade, firm, or product names is for descriptive purposes only and does not imply endorsement by the U.S. Government.

Although this information product, for the most part, is in the public domain, it also may contain copyrighted materials as noted in the text. Permission to reproduce copyrighted items must be secured from the copyright owner.

Suggested citation:

Griswold, J.P., Pierson, T.C., and Bard J.A., 2018, Modeled inundation limits of potential lahars from Mount Adams in the White Salmon River valley, Washington: U.S. Geological Survey Open-File Report 2018-1013, scale 1:75,000, 14 p., https://doi.org/10.3133/ofr20181013.

ISSN 2331-1258 (online) 


\section{Contents}

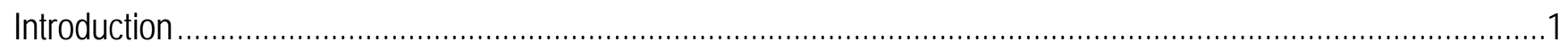

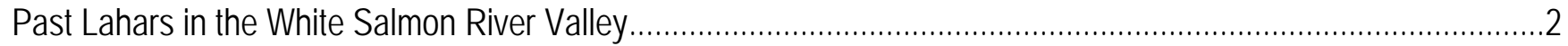

Potential for Future Lahars in the White Salmon River Valley ......................................................................

LAHARZ - Computer Model for Estimating Lahar Inundation Zones .............................................................

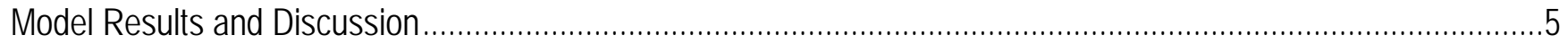

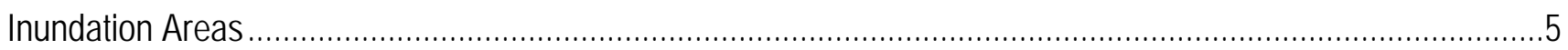

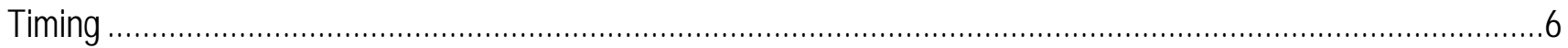

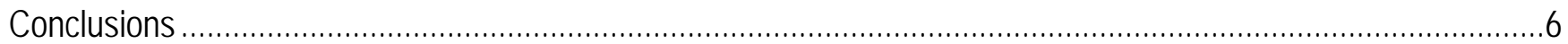

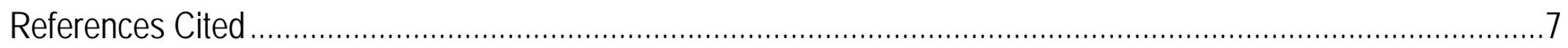

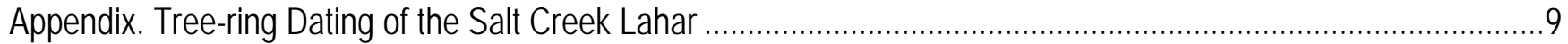

\section{Figures}

1. View of Mount Adams from the broad, flat-floored, middle White Salmon River valley near Trout Lake, Washington ..............................................................................................................10

2. View of the upper southwest flank of Mount Adams, taken from Crofton Ridge .................................11

3. Lahar-transported boulders in White Salmon River valley near Trout Lake, Washington.....................12

4. Smaller lahars and avalanches from Mount Adams ...................................................................13

5. Author (Pierson) coring a Douglas fir growing on the Salt Creek lahar deposit on the edge of a terrace at the mouth of Cascade Creek...................................................................................14

\section{Table}

1. Tree-ring data from a group of large Douglas firs growing on the Salt Creek lahar deposit at the mouth of Cascade Creek. 


\title{
Modeled Inundation Limits of Potential Lahars from Mount Adams in the White Salmon River Valley, Washington
}

\author{
By Julia P. Griswold, Thomas C. Pierson, and Joseph A. Bard
}

\section{Introduction}

Lahars large enough to reach populated areas are a hazard at Mount Adams, a massive volcano in the southern Cascade Range of Washington State (fig. 1). It is considered to be still active and has the potential to erupt again. By definition, lahars are gravity-driven flows of water-saturated mixtures of mud and rock (plus or minus ice, wood, and other debris), which originate from volcanoes and have a variety of potential triggering mechanisms (Vallance, 2000; Vallance and Iverson, 2015). Flowing mixtures can range in fluid consistency from something like a milkshake to something more like wet concrete, and they behave like flash floods, in that they can appear suddenly in river channels with little warning and commonly have boulder- or log-choked flow fronts. Lahars are hazardous because they can flow rapidly in confined valleys (commonly 20-35 miles per hour [mph] or 9-16 meters per second [m/s]), can travel more than 100 miles (mi) (161 kilometers [km]) from a source volcano, and can move with incredible destructive force, carrying multi-ton boulders and logs that can act as battering rams (Pierson, 1998). The biggest threats from lahars to downstream communities are present during eruptive activity, and impacts to communities can be dire. For example, a very large eruption-triggered lahar in Colombia in 1985 surprised and killed more than 20,000 people in a large town located about 45 mi (72 $\mathrm{km}$ ) downstream and out of sight of the volcano that produced it (Pierson and others, 1990).

Not all lahars are triggered by or associated with eruptions, however. On rare occasions, very large to extremely large lahars can be triggered by massive landslides of altered and weakened rockfailures apparently not associated with volcanic activity. For example, the Electron Mudflow, a very large lahar that was at least 250 million cubic yards $\left(\mathrm{yd}^{3}\right)$ or about 200 million $\mathrm{m}^{3}$ in volume and flowed at least $40 \mathrm{mi}$ or $64 \mathrm{~km}$, occurred at Mount Rainier about 500 years ago (Crandell, 1971; K.M. Scott and others, 1995; Reid and others, 2001). It was triggered by a massive landslide for which no evidence for concurrent eruptive activity has been found (Sisson and Vallance, 2009). In two other cases, earthquake-

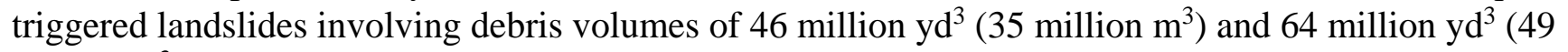
million $\mathrm{m}^{3}$ ) occurred on the flanks of quiescent volcanoes in Japan (1984) and Canada (2012), respectively (Nakaoka, 1987; Voight and Sousa, 1994; Guthrie and others, 2012). Both transformed, either partially or wholly, into lahars. Whether triggered by eruptions or not, large landslides on volcanoes commonly are associated with progressive weakening of rock high on the volcano's flanks, which is due to chemical (hydrothermal) alteration from volcanic gases (Vallance, 2000; Reid and others, 2001; John and others, 2008; Vallance and Iverson, 2015).

Mount Adams, one of the largest volcanoes in the Cascade Range, is a composite stratocone composed primarily of andesite lava flows. It has been the most continuously active volcano within the 480-mi² Mount Adams volcanic field-a region covering parts of Klickitat, Skamania, Yakima, and Lewis Counties and part of the Yakama Nation Reservation in Washington State (Hildreth and Fierstein, 
1995, 1997). About 500,000 years in age, Mount Adams reached its present size by about 15,000 years ago, primarily through the episodic effusion of lava flows; it has not had a history of major explosive eruptions like Mount St. Helens, its neighbor to the west. Timing of the most recent eruptive activity (recorded by four thin tephra layers) is on the order of 1,000 years ago; the tephras are bracketed by 2,500-year-old and 500-year-old ash layers from Mount St. Helens (Hildreth and Fierstein, 1995, 1997). Mount Adams currently shows no signs of renewed unrest.

Eruptive history does not tell us everything we need to know about hazards at Mount Adams, however, which are fully addressed in the volcano hazard assessment for Mount Adams (W.E. Scott and others, 1995). This volcano has had a long-active hydrothermal system that circulated acidic hydrothermal fluids, formed by the solution of volcanic gases in heated groundwater, through fractures and permeable zones into upper parts of the volcanic cone. Acid sulfate leaching of rocks in the summit area may still be occurring, but chemical and thermal evidence suggests that the main hydrothermal system is no longer active at Mount Adams (Nathenson and Mariner, 2013). However, these rockweakening chemical reactions have operated long enough to change about 0.4 cubic miles $\left(\mathrm{mi}^{3}\right)(1.7$ cubic kilometers $\left[\mathrm{km}^{3}\right]$ ) of the hard lava rock in the volcano's upper cone to a much weaker clay-rich rock, thus significantly reducing rock strength and thereby slope stability in parts of the cone (Finn and others, 2007). The two largest previous lahars from Mount Adams were triggered by landslides of hydrothermally altered rock from the upper southwestern flank of the cone, and any future large lahars are likely to be triggered by the same mechanism. Mount Rainier also has had extensive hydrothermal alteration of rock in its upper edifice, and it also has a history of large landslides that transform into lahars (K.M. Scott and others, 1995; Vallance and Scott, 1997; Reid and others, 2001).

The spatial depiction of modeled lahar inundation zones accompanying this report, shown in two different map perspectives, is intended to augment (not replace) the existing hazard maps for Mount Adams (W.E. Scott and others, 1995; Vallance, 1999). The maps in this report show potential areas of inundation by lahars of different initial volumes, which are determined by a computer model, LAHARZ (Iverson and others, 1998; Schilling, 1998). One map sheet presents LAHARZ-determined inundation areas on a normal plan-view shaded-relief map of the study area; the other gives an oblique perspective of the landscape with raised topography, as if one were viewing the landscape at an angle from an aircraft (Jenny and Patterson, 2007). LAHARZ was developed after the original hazard maps (based only on mapping of geologic deposits) were made. Predicted inundation zones on these maps provide an alternative approach to estimation of areas that could be inundated as lahars of different volumes pass through the valley. However, there is considerable uncertainty in the exact location of the hazard-zone boundaries shown on these maps, as well as on earlier maps (see discussion below).

\section{Past Lahars in the White Salmon River Valley}

The White Salmon River drainage basin has been inundated by past lahars, which began as landslides from the steep slopes formed in weakened rock at the head of White Salmon and Avalanche Glaciers on the southwest flank of Mount Adams (Vallance, 1999) (fig. 2). Two lahars large enough to reach the town of Trout Lake, Washington, occurred within the past 10,000 years - a period when both the physical configuration of the volcano and the regional climate have been somewhat similar to those of today. Other moderate-sized lahars and debris avalanches involving mixtures of ice, snow, and rock occurred during the same period but were not large enough to reach the now-populated area near Trout Lake; their deposits are found farther upstream along White Salmon River tributaries. Smaller lahars and avalanches traveling only a mile or two continue to occur in the upper tributaries of the White Salmon River every few years. 
The largest lahar at Mount Adams since the end of the last ice age, known as the Trout Lake mudflow, started as a landslide that quickly transformed to a lahar and swept down the White Salmon River about 6,000 calendar years ago, damming Trout Lake Creek to form Trout Lake (Vallance, 1999). The original lake is now a complex of interconnected ponds and marshland. The lahar emplaced about 86 million $\mathrm{yd}^{3}$ (66 million $\mathrm{m}^{3}$ ) of mud and rock in a deposit covering more than 6 square miles $\left(\mathrm{mi}^{2}\right)(15$ square kilometers $\left.\left[\mathrm{km}^{2}\right]\right)$, and the deposit is as thick as $65 \mathrm{ft}(20 \mathrm{~m})$ at the head of the White Salmon River valley near the town of Trout Lake (fig. 1). Hydrothermally altered clasts within the deposit, including large boulders (breccia blocks), are scattered on the flat-floored valley bottom (fig. 3), and distinctive secondary minerals in the deposit matrix indicate that the source area was the structurally weakened upper southwest flank of Mount Adams. Average thickness of the deposit in the Trout Lake area is 13 feet (ft) (4 meters [m]). Remnants of the deposit are preserved downstream as far as Husum, Washington. This lahar could have been triggered by volcanic activity, because there are 14 tephra layers from Mount Adams bracketed in age between 4,300 and 7,700 calendar years ago.

The second lahar to reach a now-populated area, the Salt Creek lahar, involved about 13 million $\mathrm{yd}^{3}\left(10\right.$ million $\left.\mathrm{m}^{3}\right)$ of mud and debris and flowed about $2.5 \mathrm{mi}(4.0 \mathrm{~km})$ into the upper end of the broad White Salmon River valley near Trout Lake, where its deposit has a maximum observed thickness of 13 $\mathrm{ft}$ (4 m) (Vallance, 1999). Originally dated as occurring in the latter half of the 18th century, more recent tree-ring dating indicates that this flow likely occurred between 1759 and 1762 (appendix). No evidence has been found to connect this lahar with eruptive activity. Furthermore, this lahar's flow path is marked by abundant, orange-colored, hydrothermally altered andesite fragments within the deposit, which indicates that the source area was also on the steep, chemically weakened upper west flank of the volcano (fig. 2) (Vallance, 1999).

Smaller lahars and debris avalanches have occurred more frequently and continue to occur on the west flank of Mount Adams, many of them involving a large proportion of snow and ice (Vallance, 1999). Deposits of several lahars of post-glacial age with volumes less than 7 million $\mathrm{yd}^{3}\left(5 \mathrm{million}^{3}\right)$ have been observed in streambanks along Cascade Creek, a major tributary of the White Salmon River. In May 1921, a mixed avalanche of snow, ice, and rock debris having a volume of about 5 million $\mathrm{yd}^{3}$ (about 4 million $\mathrm{m}^{3}$ ) flowed as far as $1.2 \mathrm{mi}(2.0 \mathrm{~km})$. It originated from the altered cliff at the head of Avalanche Glacier and descended Salt, Cascade, and Morrison Creeks. From contemporary photographs of its deposit, it appears to have been composed largely of snow and ice fragments, and its sinuous flow paths (fig. 4A) suggest it may have been partially liquefied by meltwater (for example, Pierson and Janda, 1994). Even smaller mixed avalanches and lahars continue to occur in this area with a frequency of about one per decade; recent flows were observed in 1983, 1997, 2008, 2012, and 2017 (Darryl Lloyd, written commun., 2012, 2017) (fig. 4B). None of these smaller flows have reached the Trout Lake valley, but the frequency of these failures indicates that the altered rock in the steep cliffs above the Avalanche and White Salmon Glaciers continues to be unstable.

\section{Potential for Future Lahars in the White Salmon River Valley}

Recent aerial geophysical surveys (Finn and others, 2007) indicate a large mass (about 2.4 billion $\mathrm{yd}^{3}$ or 1.8 billion $\mathrm{m}^{3}$ ) of wet, intensely altered rock occupies the summit area of Mount Adams, which refines an earlier estimate from Vallance (1999). This zone of altered rock is shaped somewhat like a bowl centered beneath the volcano's summit—a zone that is intersected by the steep cirque headwall on the upper southwest flank of the cone above the White Salmon and Avalanche Glaciers. Rock samples collected in this zone have lost up to 80-85 percent of their original rock strength (Bowman, 2002). First-order 3-D mapping of altered rock at Mount Adams (Finn and others, 2007, fig. 
11) suggests that the volume of weak rock behind and around the White Salmon and Avalanche Glaciers may approach $\sim 650$ million $\mathrm{yd}^{3}\left(500\right.$ million $\mathrm{m}^{3}$ ). Given that failed rock masses expand in volume upon disaggregation and that lahar volumes can increase significantly through entrainment of sediment and debris along a flow path, a future lahar of more than 1.3 billion $\mathrm{yd}^{3}$ or 1 billion $\mathrm{m}^{3}$ is possible. In addition, ice masses in the Avalanche and White Salmon Glaciers continue to shrink (Sitts and others, 2010), and with a possible causal connection between slope instability and currently shrinking glaciers postulated at some locations (Bovis and Jakob, 2000; Moore and others, 2009; Guthrie and others, 2012; McColl, 2012), any buttressing effect provided to the cirque headwall by these two glaciers is diminishing. Finn and others (2007) and Vallance (1999) identify these cliffs as a likely source of future small to large lahars in the White Salmon River basin.

Only two lahars have reached the Trout Lake area in the last 10,000 years (Vallance, 1999), and the chances of a future lahar large enough to affect the White Salmon River valley near Trout Lake cannot be accurately calculated but are probably very low. Probability would increase somewhat if Mount Adams were to become volcanically active again. Many unknown variables affect the likelihood and volumes of future slope failures from Mount Adams.

\section{LAHARZ-Computer Model for Estimating Lahar Inundation Zones}

A U.S. Geological Survey semi-empirical computer model (LAHARZ) can estimate the extent of potential valley inundation by lahars of different volumes (Iverson and others, 1998; Schilling, 1998). Model developers used data from 27 lahars of various sizes from nine different volcanoes to derive equations that estimate inundated-valley cross-sectional and planimetric areas as functions of lahar volume. Modeled inundation areas increase in both width and length (where not topographically constrained) as lahar volume input values are increased. LAHARZ does not predict where material will be deposited, however. Instead, it predicts what parts of the valley would most likely be inundated as a lahar passes through. However, there is no guarantee or warranty concerning the accuracy of the inundation areas. Users should be aware that temporal changes may have occurred since the model input data were collected and that some parts of these data may no longer represent actual surface conditions. The mapped inundation areas do not indicate the magnitude of the next event nor when it may occur. Users should not use these data for critical applications without a full awareness of their limitations.

Use of the LAHARZ program involves menu-driven software that runs within a Geographic Information System (GIS) utilizing a Digital Elevation Model (DEM) to objectively map areas of potential lahar inundation (Schilling, 1998). For a range of user-specified lahar volumes, LAHARZ delineates a set of nested lahar-inundation zones for progressively larger (and increasingly less probable) future lahars. These modeled inundation zones, combined with geologic mapping of deposits from past lahars, provide an objective and systematic basis for defining lahar hazard zones on U.S. Geological Survey (USGS) volcano hazard maps. The advantage of combining LAHARZ modeling with mapping is that hazard zones can be delineated where the record of past lahars is absent or unknown. The existing USGS hazard assessment for Mount Adams (W.E. Scott and others, 1995) predates LAHARZ, and its hazard map is based solely on geologic mapping. Until an updated version of the hazard assessment for Mount Adams is released, the LAHARZ-generated maps of potential lahar inundation zones in this report can be used to augment the hazard zones shown in the existing hazard map. 


\section{Model Results and Discussion}

\section{Inundation Areas}

LAHARZ was used to predict lahar inundation areas for valleys in the White Salmon River basin, using four specified volumes for the model runs: 1 million, 10 million, 100 million, and 1 billion (1,000 million) cubic meters $\left(1 \mathrm{~m}^{3}=1.3 \mathrm{yd}^{3}\right)$. These volumes represent the range of potential volumes of water-saturated rock debris that could collapse and avalanche off the upper west flank of Mount Adams plus material entrained along the flow path and transform to a lahar. The selected 1-million- $\mathrm{m}^{3}$ volume is an order-of-magnitude approximation of the "small" lahars that have occurred every few years in recent decades. The 10 -million- $\mathrm{m}^{3}$ volume approximates the volume of the Salt Creek lahar that inundated the upper White Salmon River valley near Trout Lake in the late 18th century. The 100million- $\mathrm{m}^{3}$ volume is about 50 percent larger than the volume of the Trout Lake mudflow, which inundated most of the White Salmon River valley about 6,000 years ago. The 1-billion- $\mathrm{m}^{3}$ volume represents the size of a lahar that could occur if the volume of hydrothermally altered rock in the southwestern sector of the compromised summit rock mass were to collapse. From the record of past events worldwide, such enormously large lahars are apparently triggered only when ascending magma pressurizes a hydrothermal system or structurally deforms and fractures a volcanic cone. For comparison, the volume of mostly unaltered rock that collapsed due to magmatic intrusion and cone deformation at the start of the May 18, 1980, eruption of Mount St. Helens was about 2.3 billion $\mathrm{m}^{3}$ (Voight and others, 1983).

The results of the LAHARZ model runs show that a hypothetical 1-million-m ${ }^{3}$ lahar would not reach the wide part of the White Salmon River valley near Trout Lake. A 10-million-m ${ }^{3}$ lahar would enter the upper valley, as the Salt Creek lahar did. A hypothetical 100 -million- $\mathrm{m}^{3}$ lahar would inundate the entire White Salmon River valley from Trout Lake nearly to B Z Corner, south of the town of Trout Lake. A lahar with an initial volume of 1-billion- $\mathrm{m}^{3}$ would inundate the entire White Salmon River valley and reach the Columbia River. Significant lahar deposition in the Columbia River could decrease water depth in the Columbia navigation channel, especially near the mouth of the White Salmon River; raise the water-surface elevation in the reservoir behind Bonneville Dam, downriver to the west $21.5 \mathrm{mi}$ (34.6 km), and introduce enough suspended sediment in the water to adversely affect dam operations.

The LAHARZ-predicted inundation zones in this report have significant associated uncertainties. Some uncertainty is inherent in the model itself, because (1) the 27 lahars utilized by the model to derive the equations in LAHARZ represent a small sample; (2) the accuracy of the original lahar data is not high in some cases (particularly for lahar volumes); and (3) the precision of the model results is not high and magnitude of the standard error of the predictive equations is proportional to lahar volume, with data values deviating from the best-fit regression lines by as much as a factor of five (Iverson and others, 1998). Perhaps the greatest error in utilizing this method to determine lahar hazard zones derives from the difficulty inherent in choosing the appropriate volume for the next lahar to flow down the valley. Some of the model uncertainty also is reflected in the spikiness of the inundation-zone boundaries (particularly in relatively flat terrain), which is caused in part by the model's response to subtle differences (at the pixel scale) in the digital topography of the base map and in part by the fact that the model will not force material to flow uphill (which it would actually do at flow margins on relatively flat slopes). Resolution of the base map also affects the precision of the mapped inundation zones. The USGS 7.5-minute topographic maps used to produce the digital base map for this report have horizontal resolutions of $10 \mathrm{~m}$, whereas future base maps using lidar-derived topography will have approximately 1-m resolution and are expected to have better than 10-centimeter (cm) or 3.9-inch (in) 
vertical accuracy. Therefore, inundation-zone boundaries on the maps in this report should not be viewed as precisely sharp lines.

Despite the various uncertainties inherent in using the LAHARZ model to forecast potential inundation areas, it should be noted that model results are in relatively good agreement with predicted inundation zones (hazard zones), based on geological mapping of past lahar deposits, which are shown in W.E. Scott and others (1995) and Vallance (1999). One important difference, however, is that the model uses the current topography of the valley floor, whereas the past lahars filled in a valley floor that is now buried.

\section{Timing}

The minimum time required for large lahars to reach a given area can be roughly estimated from an empirical method that correlates lahar travel times with distance from source area for lahars of different size classes (Pierson, 1998). The upstream edge of the populated valley floor near the town of Trout Lake is $17 \mathrm{mi}(27 \mathrm{~km})$ downstream of the lahar source area at the head of Avalanche and White Salmon Glaciers by way of the most likely route down Cascade Creek. Lahars of 10-million $\mathrm{m}^{3}$ —flows large enough to reach the populated area-could arrive in as little as 18-24 minutes from time of initiation. A lahar with a volume of about $100-$ million- $\mathrm{m}^{3}$ could possibly arrive in the Trout Lake area in as little as 15-20 minutes and at B Z Corner (48 km or $30 \mathrm{mi}$ downstream of source) in about 60 minutes. A low-probability 1-billion- $\mathrm{m}^{3}$ lahar could reach the Trout Lake area in as little as 10 minutes after initiation and the Columbia River in about 90 minutes.

\section{Conclusions}

Both the history of past lahars in the White Salmon River drainage and the structurally weakened state and steep slopes of the upper southwest flank of Mount Adams suggest that the next large lahar from Mount Adams may flow down one or more tributaries of the White Salmon River. The upstream edge of the populated valley floor is only $17 \mathrm{mi}(27 \mathrm{~km})$ downstream of the most likely lahar source area - the headwall above the Avalanche and White Salmon Glaciers. A lahar just large enough to reach the populated part of the White Salmon River valley near the town of Trout Lake, Washington, could do so in as little as 18-24 minutes from time of initiation. A lahar ten times that size (100 million $\mathrm{m}^{3}$ ) would likely inundate most of the White Salmon River valley floor from Trout Lake to B Z Corner, including the central part of Trout Lake town. A lahar ten times larger still ( 1 billion $\mathrm{m}^{3}$ ), extremely unlikely unless Mount Adams were reawakening from volcanic dormancy, could reach Trout Lake in as little as 10 minutes and the Columbia River (37 mi or $60 \mathrm{~km}$ downstream) in approximately 90 minutes.

Currently there is no lahar warning system in place at Mount Adams as there is at Mount Rainier, which would allow for detection of an approaching lahar and notify the populace with a warning message. The main reason is that the USGS-designed Mount Rainier system has a built-in lag time of about 30 minutes to allow for human verification, which makes it impractical for utilization at Mount Adams. Lahars large enough to reach populated areas in the White Salmon River valley could do so in less than 30 minutes. Currently, university researchers associated with the University of California Santa Barbara are testing a new lahar detection system that could more quickly detect a lahar and send an alert message. Until such a system is in place, valley residents must rely on self-detection of an approaching lahar and should learn to recognize several possible indications that a lahar could be coming toward them:

- A distant low booming sound (and possible dark dust cloud if the summit area is visible) caused a large mass of collapsing, avalanching rock. 
- A persistent low-frequency rumbling sound that slowly gets progressively louder (like an approaching freight train).

- The sudden change of clear water in the river to very muddy water, particularly if the water appears to be thickening with mud, changing its viscosity, and starting to roll boulders in the flow.

- A sudden dramatic decrease in the river flow, which could be caused by a lahar damming the river farther upstream. If the river is dammed, an outbreak flood could send a flash flood or lahar downstream hours or days later.

- Sharp cracks of breaking trees or the sight of trees being violently shaken or knocked down a relatively short distance upstream.

- A strong earthquake, a volcanic explosion (if the volcano is in a state of unrest), or exceptionally prolonged and intense rainfall; any of these, if the conditions are right, could trigger a lahar.

If any of these signs are seen or heard, people should get to high ground (at least $100 \mathrm{ft}$ above the valley floor) as quickly as possible. In the upper White Salmon River valley there is little time to waste.

\section{References Cited}

Bovis, M.J., and Jakob, Matthias, 2000, The July 29, 1998, debris flow and landslide dam at Capricorn Creek, Mount Meager Volcanic Complex, southern Coast Mountains, British Columbia: Canadian Journal of Earth Science, v. 37, p. 1321-1334.

Bowman, S.D., 2002, Modeling of volcano edifice and flank stability, and hazard zonation at Mount Adams, Washington: Reno, University of Nevada, Ph.D. dissertation, 334 p.

Crandell, D.R., 1971, Postglacial lahars from Mount Rainier volcano, Washington: U.S. Geological Survey Professional Paper 677, 75 p.

Finn, C.A., Deszcz-Pan, M., Anderson, E.D., and John, D.A., 2007, Three-dimensional geophysical mapping of rock alteration and water content at Mount Adams, Washington-Implications for lahar hazards: Journal of Geophysical Research, v. 112, B10204, 21 p., doi:10.1029/2006JB004783.

Guthrie, R.H., Friele, P., Allstadt, K., Roberts, N., Evans, S.G., Delaney, K.B., Roche, D., Clague, J.J., and Jakob, M., 2012, The 6 August 2010 Mount Meager rock slide-debris flow, Coast Mountains, British Columbia; characteristics, dynamics, and implications for hazard and risk assessment: Natural Hazards and Earth Systems Sciences, v. 12, p. 1277-1294, doi:10.5194/nhess-12-1277-2012.

Hildreth, Wes, and Fierstein, Judy, 1995, Geologic map of the Mount Adams volcanic field, Cascade

Range of southern Washington: U.S. Geological Survey Map I-2460, scale 1:50,000.

Hildreth, Wes, and Fierstein, Judy, 1997, Recent eruptions of Mount Adams, Washington Cascades, USA: Bulletin of Volcanology, v. 58, p. 472-490.

Iverson, R.M., Schilling, S.R, and Vallance, J.W., 1998, Objective delineation of areas at risk from inundation by lahars: Geological Society of America Bulletin, v. 110, no. 8, p. 972-984.

Jenny, B. and Patterson, T., 2007, Introducing plan oblique relief: Cartographic Perspectives, v. 57, p. 21-90.

John, D.A., Sisson, T.W., Breit, G.N., Rye, R.O., and Vallance, J.W., 2008, Characteristics, extent and origin of hydrothermal alteration at Mount Rainier volcano, Cascades Arc, USA; implications for debris-flow hazards and mineral deposits: Journal of Volcanology and Geothermal Research, v. 175, p. 289-314.

McColl, S.T., 2012, Paraglacial rock-slope stability: Geomorphology, v. 153-154, p. 1-16, doi:10.1016/j.geomorph.2012.02.015. 
Moore, R.D., Fleming, S.W., Menounos, B., Wheate, R., Fountain, A., Stahl, K., Holm, K., and Jakob, M., 2009, Glacier change in western North America; influences on hydrology, geomorphic hazards and water quality: Hydrological Processes, v. 23, p. 42-61, doi: 10:1002/hyp.7162.

Nakaoka, M., 1987, Geomorphological characteristics and causal factors of the 1984 Ontake landslide caused by the Naganoken-seibu earthquake: Transactions of the Japanese Geomorphological Union, v. 8, no. 2, p. 95-112.

Nathenson, M., and Mariner, R.H., 2013, Springs, streams, and gas vent on and near Mount Adams volcano, Washington: U.S. Geological Survey Scientific Investigations Report 2013-5097, 19 p., http://pubs.usgs.gov/sir/2013/5097/.

Phipps, R.L., 1985, Collecting, preparing, cross-dating, and measuring tree increment cores: U.S. Geological Survey Water-Resources Investigations Report 85-4148, 48 p.

Pierson, T.C., 1998, An empirical method for estimating travel times for wet volcanic mass flows: Bulletin of Volcanology, v. 60, p. 98-109.

Pierson, T.C., 2007, Dating young geomorphic surfaces using age of colonizing Douglas fir in southwestern Washington and northwestern Oregon, USA: Earth Surface Processes and Landforms, v. 32, p. 811-831, doi: 10.1002/esp.1445.

Pierson, T.C., and Janda, R.J., 1994, Volcanic mixed avalanches-a distinct eruption-triggered massflow process at snow-clad volcanoes: Geological Society of America Bulletin, v. 106, p. 1351-1358.

Pierson, T.C., Janda, R.J., Thouret, J.C., and Borrero, C.A., 1990, Perturbation and melting of snow and ice by the 13 November 1985 eruption of Nevado del Ruiz, Colombia, and consequent mobilization, flow, and deposition of lahars: Journal of Volcanology and Geothermal Research, v. 41, p. 17-66.

Reid, M.E., Sisson, T.W., and Brien, D.L., 2001, Volcano collapse promoted by hydrothermal alteration and edifice shape, Mount Rainier, Washington: Geology, v. 29, p. 779-782.

Schilling, S.P., 1998, Digital data set of volcano hazards for active Cascade Volcanos, Washington: U.S. Geological Survey Open-File Report 96-178, https://pubs.usgs.gov/of/1996/0178/.

Schilling, S.P., 1998, LAHARZ_-GIS programs for automated mapping of lahar-inundation hazard zones: U.S. Geological Survey Open-File Report 98-638, 80 p.

Scott, K.M., Vallance, J.W., and Pringle, P.T., 1995, Sedimentology, behavior, and hazards of debris flows at Mount Rainier, Washington: U.S. Geological Survey Professional Paper 1547, 56 p.

Scott, W.E., Iverson, R.M., Vallance, J.W., and Hildreth, Wes, 1995, Volcano hazards in the Mount Adams Region, Washington: U.S. Geological Survey Open-File Report 95-492, 11 p., 3 plates.

Sisson, T.W., and Vallance, J.W., 2009, Frequent eruptions of Mount Rainier over the last 2,600 years: Bulletin of Volcanology, v. 71, p. 595-618, doi: 10.1007/s00445-008-0245-7.

Sitts, D.J., Fountain, A.G., and Hoffman, M.J., 2010, Twentieth century glacier change on Mount Adams, Washington, USA: Northwest Science, v. 84, no. 4, p. 378-385, doi: http://dx.doi.org/10.3955/046.084.0407.

Vallance, J.W., 1999, Postglacial lahars and potential hazards in the White Salmon River system on the southwest flank of Mount Adams, Washington: U.S. Geological Survey Bulletin 2161, 49 p., 2 plates.

Vallance, J.W., 2000, Lahars, in Sigurdsson, H., Houghton, B.F., McNutt, S.R., Rymer, H., and Stix, J., eds., Encyclopedia of volcanoes: San Diego, Calif., Academic Press, p. 601-616.

Vallance, J.W., and Iverson, RM., 2015, Lahars and their deposits, in Sigurdsson, H., Houghton, B., McNutt, S.R., Rymer, H., and Stix, J., eds., Encyclopedia of volcanoes (2nd ed.): Amsterdam, Elsevier/Academic Press, p. 649-664.

Vallance, J.W., and Scott, K.M., 1997, The Osceola Mudflow from Mount Rainier-Sedimentology and hazard implications of a huge clay-rich debris flow: Geological Society of America Bulletin, v. 109, p. 143-163. 
Voight, Barry, Janda, R.J., Glicken, Harry, and Douglass, P.M., 1983, Nature and mechanics of the Mount St. Helens rockslide-avalanche of 18 May 1980: Géotechnique, v. 33, p. 243-273.

Voight, B., and Sousa, J., 1994, Lessons from Ontake-san-A comparative analysis of debris avalanche dynamics: Engineering Geology, v. 38, p. 261-297.

\section{Appendix. Tree-ring Dating of the Salt Creek Lahar}

Previous radiocarbon and tree-ring dates have indicated that emplacement of the Salt Creek lahar deposit occurred between A.D. 1660 and 1780, probably in the second half of the 18th century (Vallance, 1999). To narrow this age range, a stand of old-growth Douglas fir trees growing on the Salt Creek lahar deposit was located on a terrace at the confluence of Cascade Creek and the White Salmon River (lat 4606'18.87" N., long 12136'28.06" W.). This grove contained no stumps to indicate previous logging, and the terrace deposit was mapped as Salt Creek lahar by Vallance (1999) and had the characteristic intense orange color imparted by alteration products in that deposit. On June 23 and 24, 2014, T.C. Pierson and Darryl Lloyd cored six of the largest (and presumed among the oldest) living trees in this stand using a standard increment borer at breast height (fig. 5). Breast height (BH) is defined as approximately $4.6 \mathrm{ft}(1.4 \mathrm{~m})$ above the ground surface, although it varies with the site and with the height of the person coring. Cores were mounted, prepared, and interpreted using standard procedures (Phipps, 1985), and rings were counted using a binocular microscope. The table below presents the results.

Table 1. Tree-ring data from a group of large Douglas firs growing on the Salt Creek lahar deposit at the mouth of Cascade Creek, on the southwest flank of Mount Adams. Methods for estimating time to grow to breast height (BHGT) and the lag time between emplacement of the lahar deposit and germination of the first group of colonizing Douglas firs (GLT) are from Pierson (2007).

\begin{tabular}{|c|c|c|c|c|c|c|c|c|c|}
\hline Tree ID & Ring count & $\begin{array}{c}\text { Tree radius } \\
\text { from oldest } \\
\text { ring to } \\
\text { center }(\mathrm{mm})\end{array}$ & $\begin{array}{l}\text { Average } \\
\text { thickness of } \\
\text { five oldest } \\
\text { rings }(\mathrm{mm})\end{array}$ & $\begin{array}{c}\text { Estimated } \\
\text { no. of } \\
\text { missing } \\
\text { rings }\end{array}$ & $\begin{array}{c}\text { No. of rings } \\
\text { to center at } \\
\text { breast } \\
\text { height }\end{array}$ & $\begin{array}{l}\text { BHGT } \\
\text { (years) }\end{array}$ & $\begin{array}{c}\text { Tree age } \\
\text { (years) }\end{array}$ & GLT ( years) & $\begin{array}{c}\text { Estimated } \\
\text { age (years } \\
\text { before 2014) } \\
\text { when } \\
\text { deposit } \\
\text { emplaced }\end{array}$ \\
\hline T1 & 232 & 35 & 4.5 & 7 & 239 & 6 & 245 & 5 & 250 \\
\hline T2 & $\sim 225$ & ? & ? & est. 5 & 230 & 6 & 236 & 5 & 241 \\
\hline $\mathrm{T} 5$ & 219 & 28 & 3.3 & 8 & 227 & 6 & 233 & 5 & 238 \\
\hline T6 & 230 & 40 & 6.1 & 6 & 236 & 6 & 242 & 5 & 247 \\
\hline
\end{tabular}




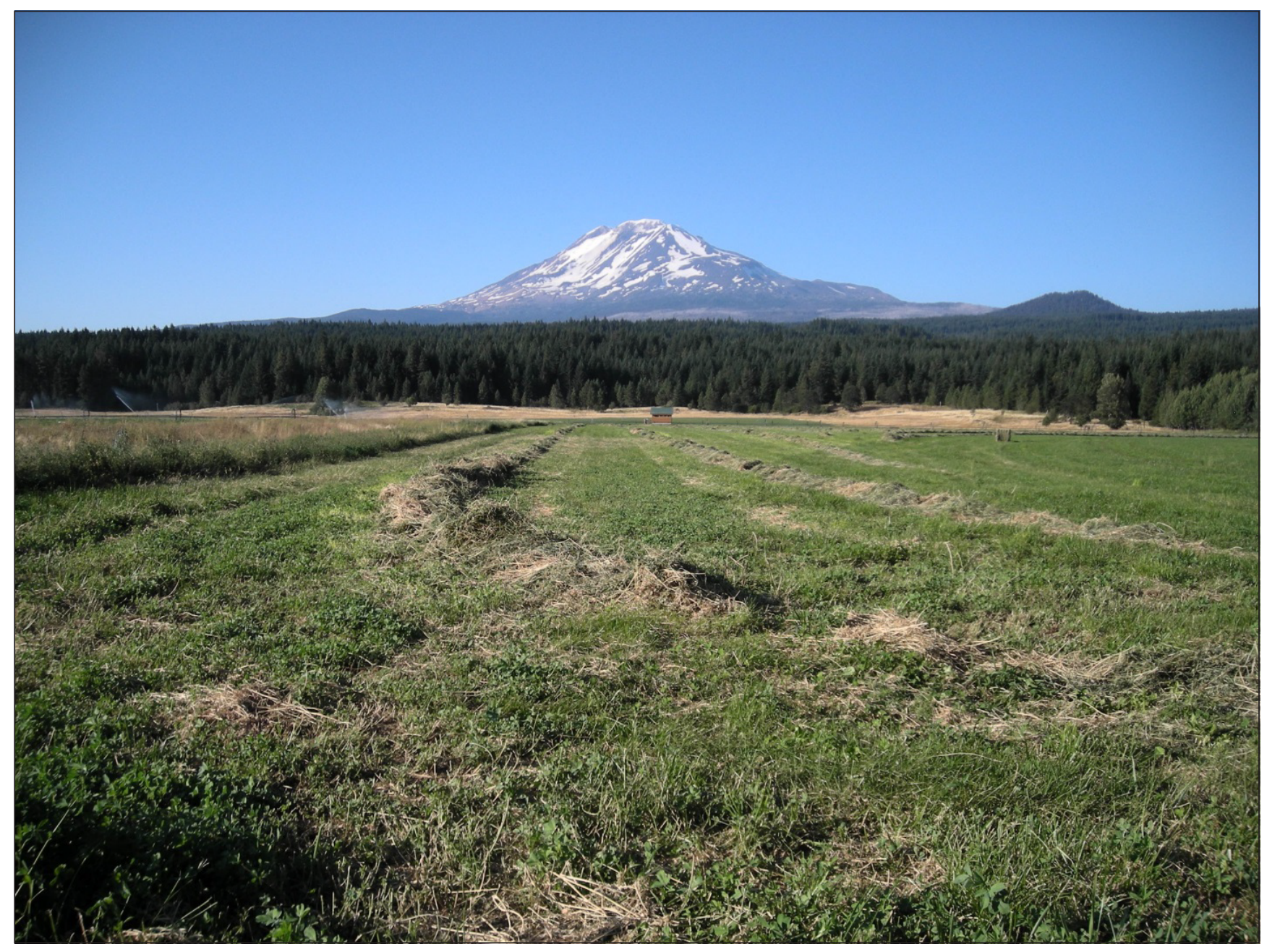

Figure 1. View of Mount Adams, looking north, from the broad, flat-floored, middle White Salmon River valley near Trout Lake, Washington, about $5 \mathrm{mi}(8 \mathrm{~km})$ downstream from the head of the populated part of the valley. The volcano summit is about $20 \mathrm{mi}(32 \mathrm{~km})$ upstream from this point, and all of the fields in this view are underlain by a thick deposit from a lahar that swept down from Mount Adams about 6,000 years ago. USGS photo by T.C. Pierson 2017. 


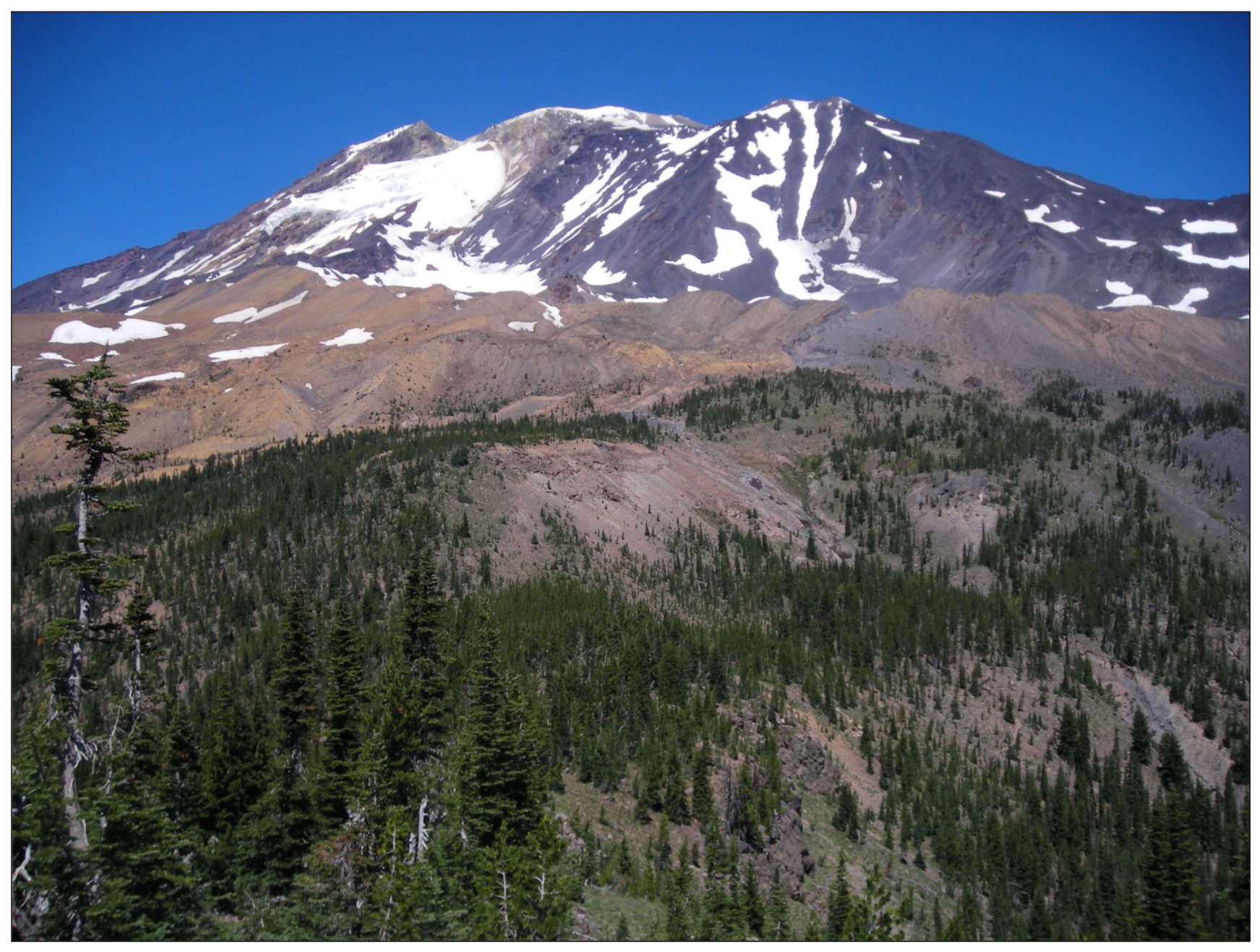

Figure 2. View of the upper southwest flank of Mount Adams, taken from Crofton Ridge. The large, multi-lobed white patch just left of the summit is a composite of two adjacent glaciers-the White Salmon Glacier on the left and the Avalanche Glacier on the right. The two glaciers occupy a cirque with a very steep headwall. Much of the terrain between the upper cone and the left foreground has been swept by past lahars. The orange-colored material in the less-vegetated areas is the Salt Creek lahar deposit. USGS photo by T.C. Pierson, 2007. 

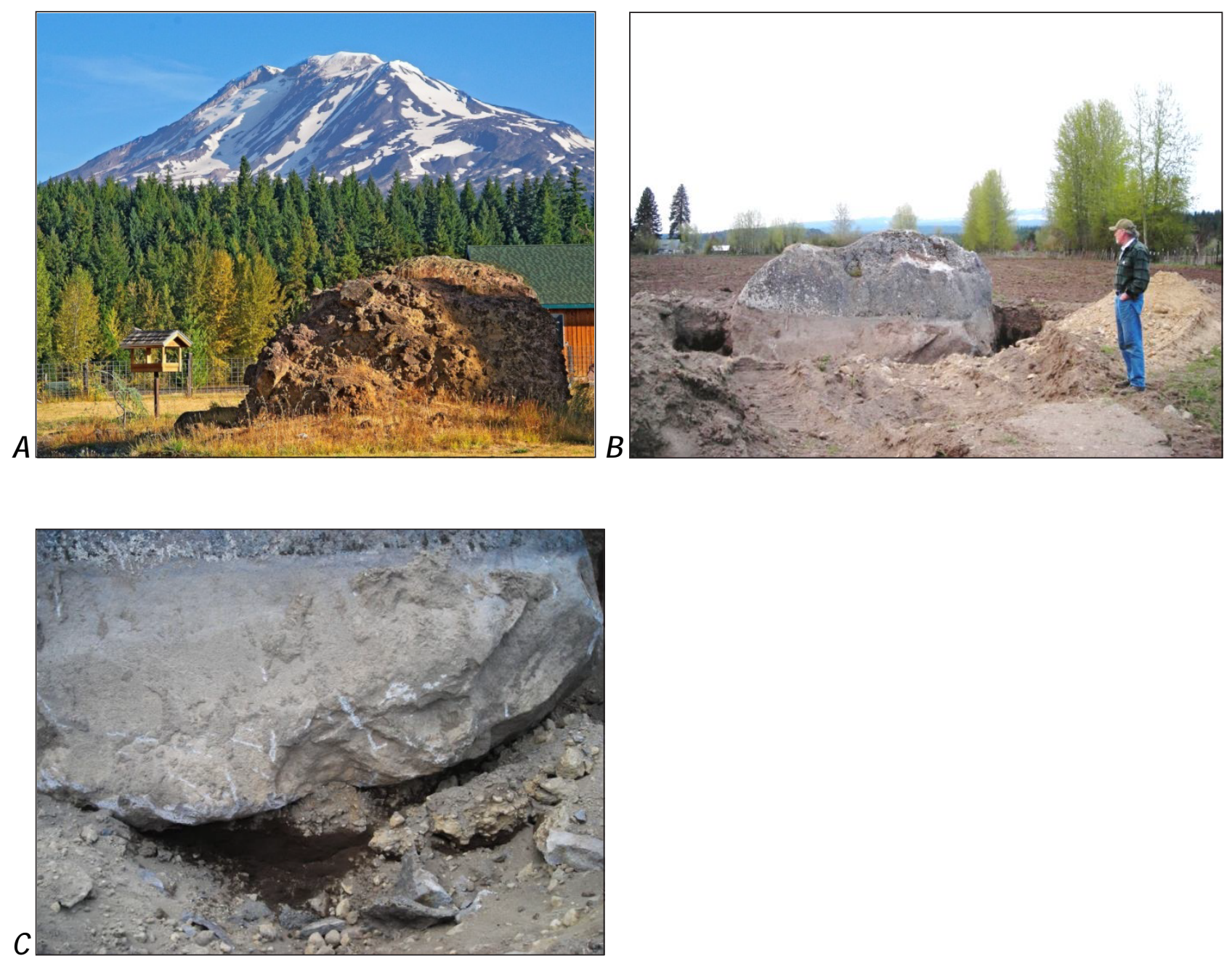

Figure 3. Lahar-transported boulders in White Salmon River valley near Trout Lake, Washington, located about $17 \mathrm{mi}(27 \mathrm{~km})$ downstream of their source on the southwest flank of Mount Adams: $A$, Boulder of altered volcanic breccia about $10 \mathrm{ft}$ or $3 \mathrm{~m}$ in diameter. $B$, Boulder of andesite lava, averaging about $7 \mathrm{ft}(2 \mathrm{~m})$ in diameter, being excavated from pasture. $C$, Base of boulder shown in $B$, underlain by poorly sorted lahar deposit. Photo $A$ by Darryl Lloyd, 2011, used with permission; USGS photos $B$ and $C$ by T.C. Pierson, 2011. 
A

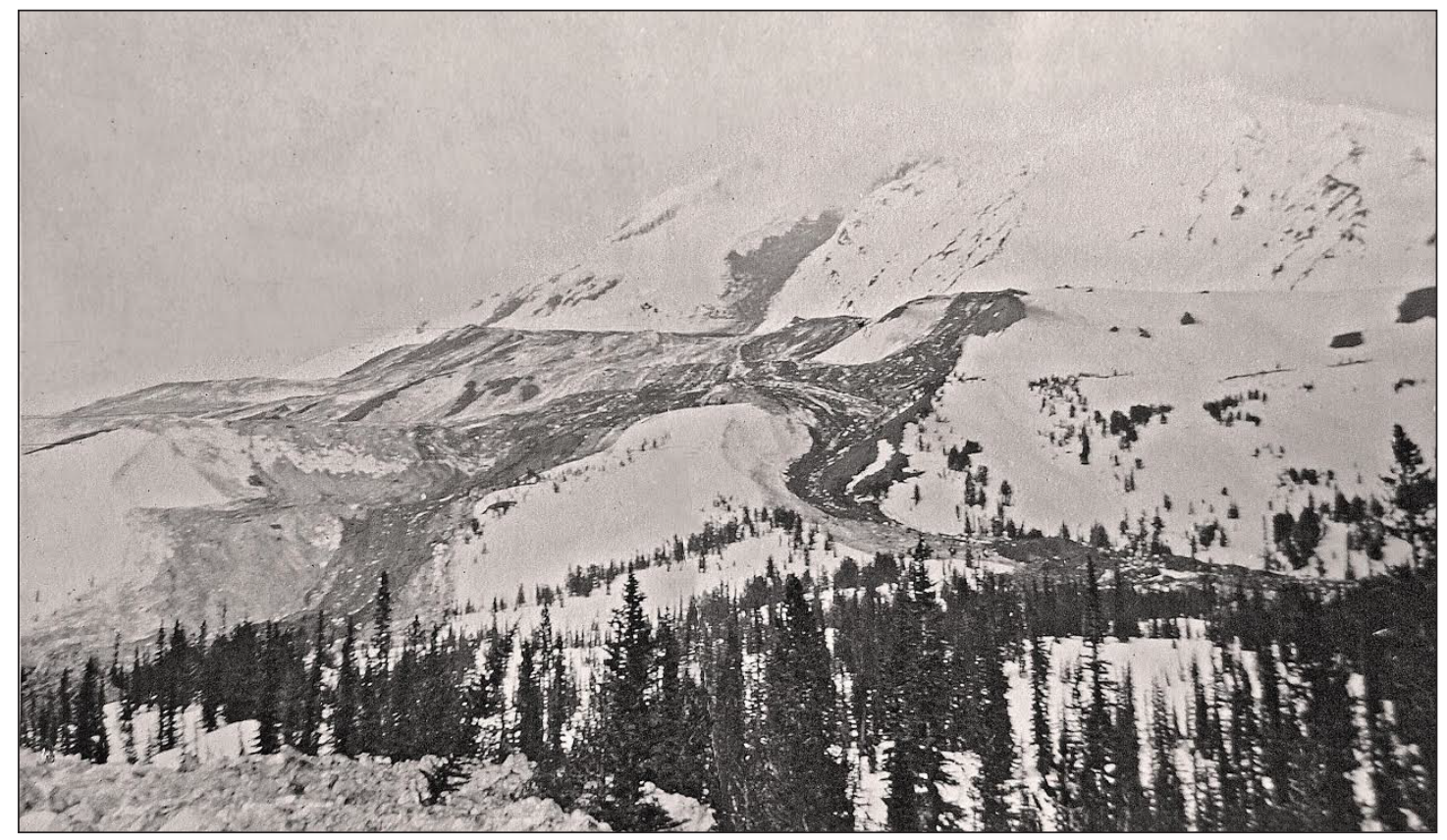

B

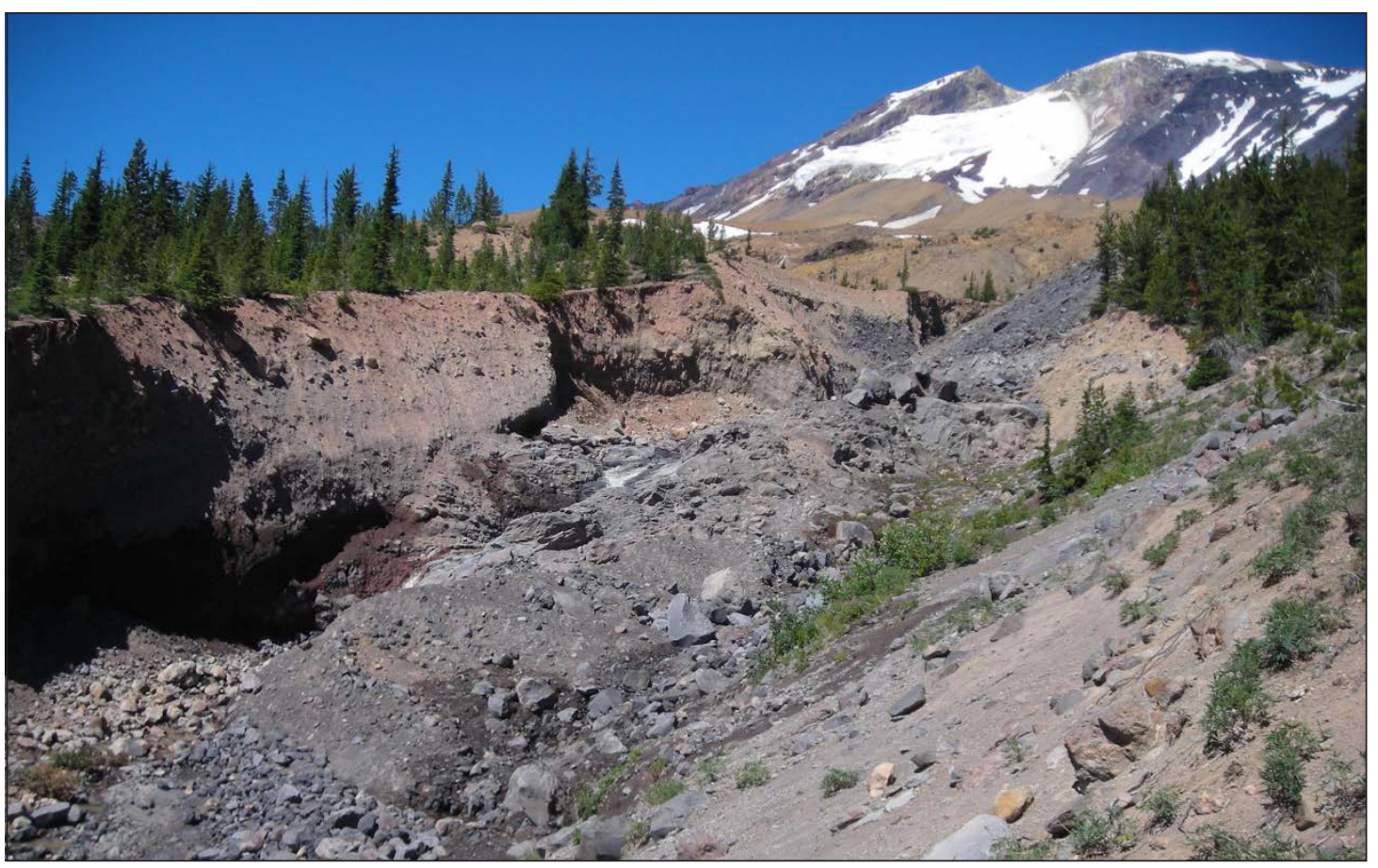

Figure 4. Smaller lahars and avalanches from Mount Adams. A, Deposit and complex flow path of the 1921 mixed avalanche, photographed shortly after occurrence. Photo by Arthur Jones, U.S. Forest Service,1921, from the collection of Darryl Lloyd of historic photos of Mount Adams, used with permission. $B$, Channel of Salt Creek on the southwest flank of Mount Adams, showing intense scouring by a small lahar (debris flow) in 2007. A gray levee deposit from that flow is on the near side of the channel, and deposits of older lahars are visible in the far channel bank, including the Salt Creek lahar deposit (orange-brown unit on top of section). This 2007 lahar did not reach very far beyond this point. USGS photo by T. Pierson, 2007. 


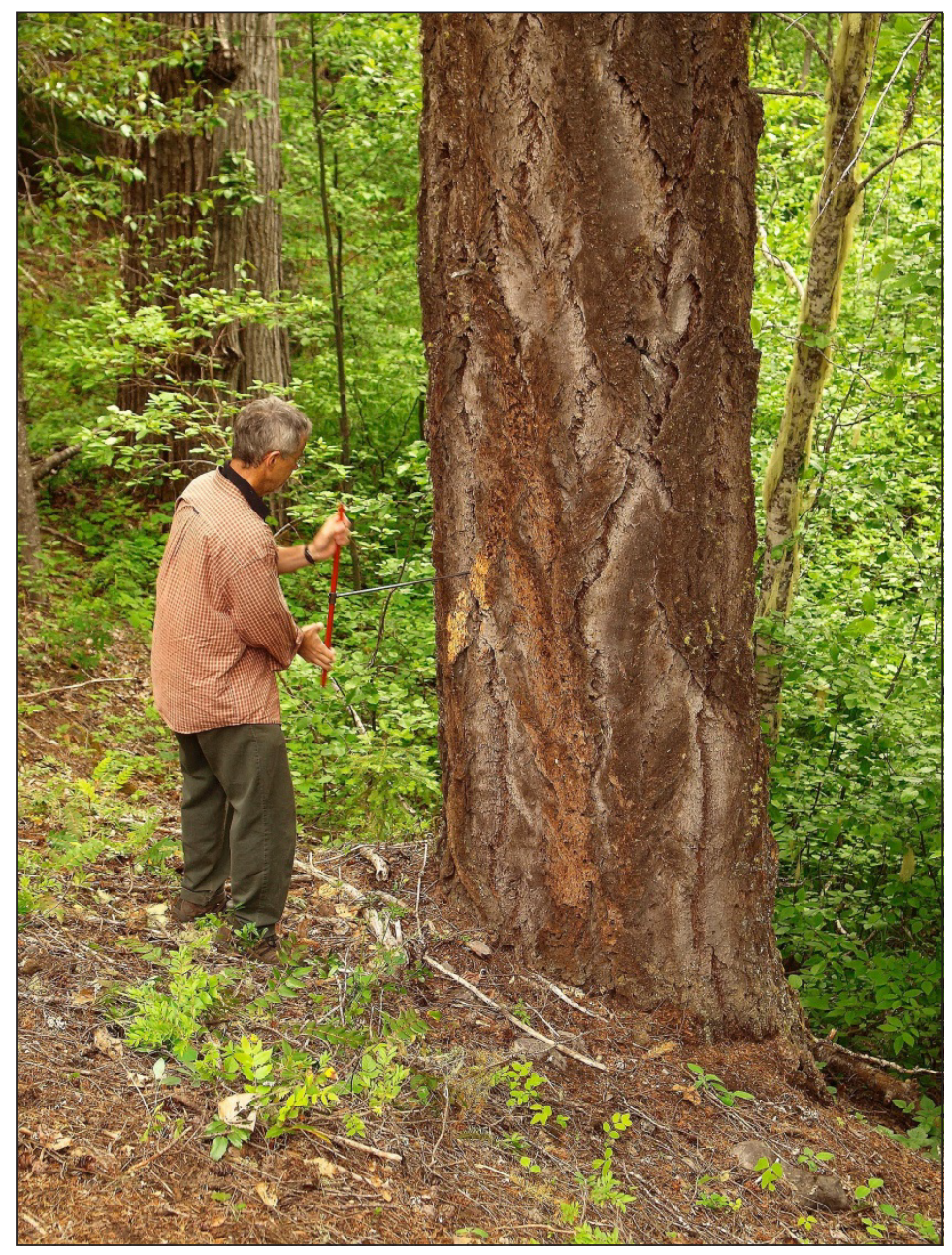

Figure 5. Author (Pierson) coring a Douglas fir growing on the Salt Creek lahar deposit on the edge of a terrace at the mouth of Cascade Creek, on the southwest flank of Mount Adams. This tree is presumed to be among the first group of Douglas firs to colonize this lahar deposit. Photo by Darryl Lloyd, 2014, used with permission. 